\title{
Learning Writing through Psychowriting Perspective
}

\author{
Anas Ahmadi ${ }^{1 *}$, Syamsul Sodiq ${ }^{1}$, Slamet Setiawan ${ }^{2}$, Yuni Pratiwi ${ }^{3}$, Nuria Reny Hariyati ${ }^{4}$ \\ ${ }^{1}$ Department of Indonesian Language and Literature, Universitas Negeri Surabaya, Indonesia \\ ${ }^{2}$ Department of English Education, Universitas Negeri Surabaya, Indonesia \\ ${ }^{3}$ Department of Indonesian Literature, Universitas Negeri Malang, Indonesia \\ ${ }^{4}$ Akademi Farmasi, Surabaya, Indonesia
}

Corresponding Author: Anas Ahmadi, E-mail: anasahmadi@unesa.ac.id

\section{ARTICLE INFO}

Article history

Received: September 12, 2018

Accepted: November 15, 2018

Published: February 28, 2019

Volume: 10 Issue: 1

Advance access: January 2019

Conflicts of interest: None

Funding: None

Key words:

Psychowriting,

Psychological Personality,

Learning Writing

\begin{abstract}
All this time, writing is widely viewed from various perspectives, such as fragmentary and/ or integrative (mono-disciplinary studies), interdisciplinary studies, and multidisciplinary studies. In this article, learning writing based on psychowriting in the Department of Indonesian Language and Literature, State University of Surabaya is presented. Based on the results of the study, it was found that psychowriting-based writing lesson improves students' writing skill, writing effectiveness, and the understanding of students' psychological personality.
\end{abstract}

\section{INTRODUCTION}

Writing is an urgent matter in academic context. Someone is considered academic when their writing works including journal, book, or research are widely published. Logically, the more someone produces writing, the more academic the person is. Although, on the other hand, the number of writing produced is considered as the parameter of someone's academic credibility. As broadly known that plagiarism and ghostwriter case are sometimes inseparable from the writing world. The plagiarism case in Indonesia is not a trivial thing. Based on media surveys, academics in Indonesia who had allegedly done plagiarism including students, lecturers, professors, and even ministers.

Indeed, writing is not an easy matter, but it is not a difficult stuff either. Many obstacles encountered when someone writing. Starting from prewriting, writing process, and postwriting. Some researchers, for example, Suparno (2007) and Yulianto (2008) showed that the low quality of writing was caused by the disinterest of academics in writing. In the context of university students, there are three main factors underlying the problem in writing, they are (1) the lack of students' maximum interest in writing; (2) the lecturer that are not motivative and attractive; and (3) unsupportive environment. It could be that
Swander, Leahly, and Cantrell $(2007 ; 15)$ narrated that "writing cannot be taught." Therefore, pessimism sometimes popped up in mind and shackled someone to write optimally.

Several studies in improving writing ability have been conducted in which the focus is on giving mentoring breakthrough in writing (William \& Takkaku, 2011) and offering internet-based learning (Kirkpatrick \& Klein, 2016). In addition, writing is usually related to language skills (listening, reading, speaking, and writing) in integrative language learning context as explained by Mmela (2006) who relates the four skills to literation.

Being recognized or not, Indonesia is still 'walking' in terms of writing (Ahmadi, 2012; 2014; 2015). This matter can be seen from the number of Scopus-indexed journals. In 2016, Indonesia has had only 20 journals while Singapore and Malaysia have already had around 50 journals. Why are we left behind compared to the "next-door countries?" The apologia answer is that because we are indeed a younger nation compared to the "next-door countries." Is it because of less optimal strategy? Is it because of the teachers? Or is it because of the environment? However, those things are not the reasons why we are left behind. Therefore, this paper offers interdisciplinary study between writing and psy- 
chology. This pairing of psychology and writing is based on several factors; (1) the minimum (or even unavailable) writings/studies about the psychology of writing in Indonesia and (2) the attempt to combine psychology and writing, and vice versa, since both are interconnected.

\section{LITERATURE REVIEW}

\section{Psychowriting}

Writing is not a science similar to Mathematics, Physics, or Chemistry. Indeed, in this context, it is related to the core to all fields. As we know that Mathematics, Physics, and Chemistry are related to calculation and numbers. However, in writing, a mental process is involved. This mental process produces a writing starting from thoughts transformed into scripts. That mental process cannot be separated from psychology since writing is closely related to psyche (soul). Psychology contributes to language (writing), and language (writing) contributes to psychology as well. This interrelation is called psychowriting (Syamsul, Kamidjan, \& Ahmadi, 2016a;2016b).

Humans are homo symbolicum, creatures that create symbols and live in the world of symbols. In expressing the symbols and ideas in their mind, humans put them in the form of writing. Since ideas and writing are related, writing can be said as the concretization of thinking (Kellogg, 1994:14). Through concrete thoughts, we can understand someone's writing and how their way of thinking. This matter cannot be separated from human nature as homo scriptor, creatures that create writing and live in the world of writing.

The world of psychology does make a very big contribution to the world of writing. A person can never manage to write well if he does not have good passion. In fact, in the context of writing, even when a person is in the toilet, he may get a good and brilliant idea. Therefore, writing is not the same as doing Mathematics. There are also some writers who enjoy writing when they are in coffee shops along with their optimal interest. Eventually, the writing is born in that place.

\section{Personality Typology}

\section{Existentialism}

Existentialism as in psychology cannot be separated from the influence of the philosophy of existentialism. The philosophy of existentialism is a philosophy of being. Therefore, this philosophy is a philosophy of action, not a philosophy of ideas. This philosophy defies the thinking of Rene Descartes stating cogito ergo sum (I think, I exist), while existentialist clearly stated sum cogito ergo (I exist, I think). As a philosophy, existentialism is regarded as a radical philosophy since it has an extreme view about the existence of human beings on earth.

The great ideas promoted by philosophy of existentialism are (1) human thoughts should dwell on and defend the antithesis of subject and object. Human as subject is not an object of thought and cannot be the object of investigation and practical manipulation as made by rationalists. Existentialists also reject the scientific view of human as a personal point and (2) freedom means human is no longer an object formed under the influence of necessity and social nature. Humans form themselves by their actions and deeds. A human is free to take responsibility for what he has done and does not justify himself based on the things surrounding him. Therefore, human is responsible for everything happened in history (Bagus, 2005:186). Thus, this philosophy has a high conception of egoism.

Existentialism developed in the XX century in France and Germany (Lavine, 2003:9). Existentialism as a philosophy actually cannot be separated from the reaction of materialism and idealism (Drijakara, 1979:57; Leahly 1985:54). The views of materialism and idealism are too extreme in looking at human. Materialism views the lower angle of human and considers that angle as a whole. While idealism views the upper angle of human and considers that as the whole thing of human. Existentialism as a philosophy, in fact, turns out to be somewhat different from other philosophies. Existentialism has never been a course or movement. More precisely, there is a mutual resemblance among existential thinkers in terms of the issues proposed and how they perceive their position in the universe (Smith \& Raeper, 2000:76). This is in line with Hassan's view (1992:1) that people have difficulty in defining existentialism with a single formulation since its philosophers showed differences in defining existence itself. The only thing in common between them is the agreement that philosophy should start from concrete human, that is, human as existence and in connection with this point of departure, they stated that for human, existence precedes the essence.

\section{Behaviorism}

While existentialism puts forward the internal factors; selfhood, egoism, and subjectivity as the former of success or not success, behaviorism is the opposite. In the view of behaviorism, factors playing important role in psyche of the human being is the environment. The conditioning brought about by external factors is the main factor that determines a person's psyche.

Behaviorism--pioneered by J.B. Watson-is one of the branches of psychology trying to raise more concrete things since it is related to the measurability. If something cannot be real and concretely measured, it is difficult to be accounted for. In addition, its degree of validity is extremely low. Therefore, the behaviorists put fowward the measurability and concreteness. Indeed, this is one of the distinguish features between behaviorism with other fields of psychology, such as existential, psychoanalysis, and humanistic.

Behaviorism figure, B.F. Skinner, raised the term operan conditioning, in this case, there are two aspects, namely respondents and operands. The respondents' behavior is a specific response generated by a known stimulus. The stimulus always precedes the response, for instance, respondents narrowing the pupil to reduce light stimulation, respondents salivated when looking at food, etc. In later stages, Ivan Pavlov brought up the term classical conditioning which used dog experiment. When the food was presented, the dog salivated (Koswara, 1991:78). The study of this behaviorism model got criticism since it equates human with animal. The term 
conditioning and response stimulus are a contribution of the world of behaviorism. In the context of response stimulus, an individual will tend to repeat the existing behavior with reward and stop the one with punishment.

\section{Psychoanalysis}

As the -ism of psychology, psychoanalysis is the oldest among the behavioral, humanistic, or even holistic psychology. Essentially, psychoanalysis is the -ism of psychology which directs the understanding, healing, and prevention of mental illness by free association method (Koswara, 1990:9; Caplin, 2009:394). Psychoanalysis is a psychology that opposes traditional psychology which tends to focus on the consciousness. In fact, in Freud's view, psychology actually tends to the unconsciousness since the structure of human personality is like an iceberg in the ocean. The tip of the iceberg coming to the surface of the water is the realm of consciousness, while the ice undersea is the realm of unconsciousness. Therefore, in the view of psychoanalysis, human beings are driven by the unconscious nature than the conciousness.

In that realm of unconsciousness, there is a subconscious that is difficult to reach by the realm of human consciousness. Thus, the subconscious sometimes occurs spontaneously or unintentionally when human sleeps. In sleep, the threshold between the conscious and the subconscious becomes slightly looser. Therefore, sometimes, a person is delirious and revealing what he buried deeply. When the person awakens, he does not remember at all that he was delirious and revealing the secrets he has so deeply buried.

In the context of psychoanalysis, the famous figures are Sigmund Freud, Carl Gustav Jung, Erich Fromm. All three, though have different views in psychoanalysis, still have the same soul; the psychoanalysis itself. Deeply examined, Sigmund Freud sided to pansexuality, Carl Gustav Jung sided to mystical psychoanalysis, and Eric Fromm sided to the psychoanalysis-philosophy and psychosocial.

\section{Humanistic}

Humanistic psychology, in fact, is not a single organization of a theory or system, but a movement. Maslow himself considered it a third force. Although figures in this movement have different views, but they are based on the same fundamental conception about human rooted in one of the modern philosophies, which is existentialism. Maslow's humanistic psychology is not a false rejection of Freud's and Watson's work, or even other behaviorists, but rather a useful, meaningful, and applicable aspect of the study of humanity in both psychologies. Therefore, he started from that view. It is very difficult for Maslow to say respect and resentment to these two most compassionate psychologists. In his opinion, someone is too easy to self-declare as freudian or antifreudian, pro scientific psychology or anti scientific psychology, and so on. Maslow found that most successful psychologists or psychiatrists often had to deviate from popular theories for the sake of their success in handling neurotic and psychotic patients. Various existing theories, in fact, could not solve humanitarian problems and apparently unable to to ex- plain the facts occurred in the real setting. Maslow strongly objected Freud's theory focusing on investigation of people with neurotic and psychosis disorders as well as the assumptions that all forms of behavior are the result of learning rather than natural things that human beings have had since they were born (Hall dan Linzey, 1993:34). Hence, the thought of Abraham Maslow is regarded as the third thought. The first is Freud's with his psychoanalysis examining the neurotic and psychosis. While the second thought is behaviorism examining people.

\section{RESEARCH METHOD}

\section{Research Approach}

This research used qualitative approach since it emphasizes the discussion using description and narration (Creswel, 2009). Qualitative approach in this reseach described, narrated, and interpreted texts related to psychowriting.

\section{Research Subject}

The subjects of this research were 40 university students in the fourth semester of the Department of Indonesian Language and Literature, State University of Surabaya.

\section{Data Collection}

The data collection in this study was divided into two terms. The first term was conducted on 25-29 April 2017 (prewriting stage). The second term was conducted on 2530 April 2018 (writing and post-writing stage).

\section{DISCUSSION}

The steps in learning writing based on psychowriting.

\section{Preparation (Prewriting)}

The lecturer distributed the questionnaires concerning writing to the students. The problems given are related to the obstacles that might occur in the writing process. Besides distributing questionnaires, the lecturer conducted unstructured interviews with the students to deepen the understanding of their obstacles in writing.

\section{Writing Process}

The lecturer provided psychowriting-based writing materials. After the learning materials were given, a question and answer session was conducted to strengthen and sharpen psychowriting materials. At the assignment stage, students were asked to write short stories that suit their interests.

\section{Post-writing}

After the writing process, the task was submitted to the lecturer. The next stage is psychowriting-based writing assessment. The assessment in psychowriting is divided into two, namely peer assessment and assessment by lecturer. Af- 
ter the assessment, the lecturer started to give evaluation and the students gave reflection through questionnaires given by the lecturer.

\section{RESULT AND DISCUSSION}

\section{Prewriting Stage}

Based on the results of questionnaires and interviews with students, the data obtained is as follows.

First, related to the learning of writing associated with psychology, $80 \%$ of the students answered strongly agree. There were $10 \%$ answered agree and the remaining $10 \%$ answered neutral.

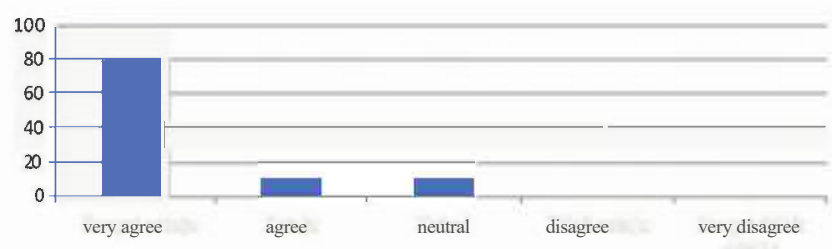

Second, the students' statement about the importance of psychowriting-based writing showed 70\% students strongly agreed with psychowriting-based writing lessons, $20 \%$ students agreed and the remaining 10\% chose to be neutral. Based on the interview results, the students mostly agreed with psychowriting-based writing lesson because psychowriting is a relatively new learning for them.

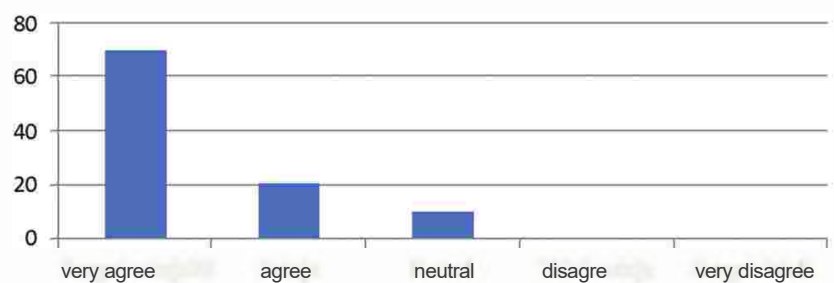

Third, related to the effectiveness of using psychowriting-based learning, the questionnaire results showed $80 \%$ students strongly agreed that psychowriting lesson is very effective in improving and helping them to write. There were $10 \%$ students chose to be neutral and the remaining $10 \%$ did not even know whether the lesson can improve their writing skill or not.

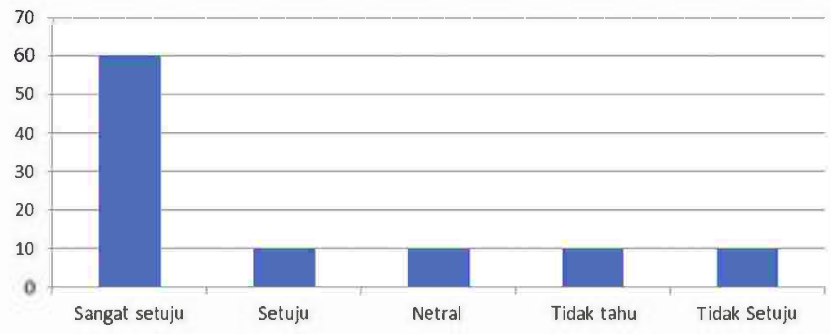

\section{Post-writing Stage}

Based on the writing results of the students who got psuchowriting-based writing lesson, it was revealed that
$60 \%$ students strongly agreed with the effectiveness of psychowriting-based writing lesson. While $10 \%$ of the students agreed with the lesson and $10 \%$ chose to be neutral;. However, there are $10 \%$ students who had no idea about the effectiveness.

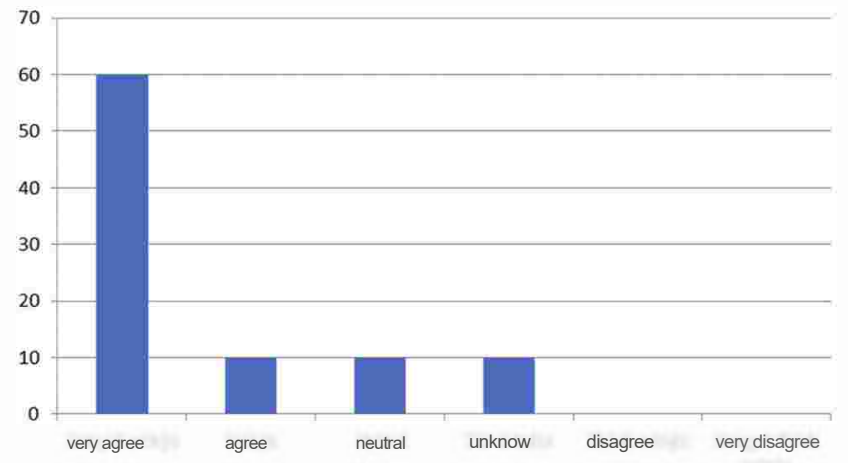

To deepen the understanding about the effectiveness of writing lesson, the interview results between lecturer and the students resulted in the following (1) the students felt more comfortable in writing because they could recognize themselves when writing; (2) during the writing lesson, it did not really "touch" psychological issues. Although in fact, learning psychology is very useful when associated with writing.

\section{CONCLUSION}

Psychowriting in learning writing is an integration between psychology and writing. Based on the results of the study, it was found that the students were very enthusiastic about writing based on psychowriting. Psychowriting is an offer in boosting academic or non-academic writing skills. Of course, as a new offer, it still lacks of many things. However, there is one main thing in this paper that can be used as reference/comparison in improving writing skills is to understand writing through psychology which had been somewhat disregarded.

\section{REFERENCES}

Ahmadi, A. (2012). Explicatus Instinctus Menulis. Paper presented in Auditorium FBS, Unesa.

Ahmadi, A. (2014). Menulis Jurnalistik Perspektif Psikologi Menulis. Paper presented in Pacet, East Java.

Ahmadi, A. (2015). Psikologi Menulis. Yogyakarta: Ombak. Creswell, J. W. (2009). Research Design, Qualitatif, Quantitative, and Mixing Approaches. London: Sage.

Dagun, S.M. (1990). Filsafat Eksistensialisme. Yogyakarta: Rhineka Cipta.

Drijakara, S.J. (1979). Percikan Filsafat. Jakarta: Pembangunan.

Freud, S. (2001). Psikoanalisis. Trans. Yogyakarta: Ikon. Goble,

F. (2000). Psikologi Humanistik. Trans. Yogyakarta: Kanisius.

Hassan, F. (1992). Berkenalan dengan Eksistensialisme. Jakarta: Pustaka Jaya.

Kellogg, Ronald T. (1994). The Psychology of Writing. New York: Oxford.

Lavine, TZ. (2002). Dari Socrates ke Sartre. Yogyakarta: Jendela. 
Lavine, TZ. (2003). Sartre: Filsafat Eksistensialisme Humanisme. Yogyakarta: Jendela.

Nietzsche, F. (2001). Zarathustra. Diterjemahkan oleh HB Jassin dkk. Yogyakarta: Bentang.

Nietzsche, F. (2004). Ecce Homo. Translated by Omi Intan. Yogyakarta: Pustaka pelajar.

Kirkpatrick, L.C. \& Klein, P.D. (2016). High-achieving High School Students' Strategies for Writing from Internet-based Sources of Information. Journal of Writing Research, 8 (1), 1-47

Mmela, E. (2006). Implementing Integrated Literacy Approaches in an English Classroom in Malawi. Dissertation unpublished. Virgiania: Virginia Polytechnic Institute and State University.

Poduska. (2000). Empat Teori Kepribadian. Terj. Jakarta: Restu.

Swander, M. Leahly, A. \& Cantrell, M. (2007). Theories of Creativity and Creative
Writing Pedagogy. In Steven Earnshaw (ed.). The Handbook of Creative Writing.Edinburg: Edinburg University Press.

Sartre, J.P. (2001). Les Mots. Terj. Jakarta: Gramedia.

Sartre, J.P. (2009). Words. Terj. Yogyakarta: Selasar.

Sutrisno, M. \& Hardiman, B. (Ed.). (1992). Para Filsuf Penentu Gerak Zaman. Yogyakarta: Kanisius.

Suparno. (2007). Keterampilan Menulis. Jakarta: UT.

Syamsul, S. Kamidjan, Ahmadi, A. (2016a). Strategi Menulis Berbasis Psychowriting. Surabaya: Unesa Press.

Syamsul, S. Kamidjan, Ahmadi, A. (2016b). Pengembangan Keterampilan Menulis Berbasis Psychowriting untuk Meningkatkan Literacy Writing. Surabaya: Risearch report. LPPM Unesa.

Williams, D.J. \& Takaku, S. (2011). Help seeking, self-efficacy, and writing performance among college students. Journal of Writing Research, 3(1), 1-18

Yulianto, B. (2008). Menulis Teknis. Surabaya: Unesa Press. 